\title{
Molecular detection and phylogenetic relationship of wild-type strains of canine distemper virus in symptomatic dogs from Uberlândia, Minas Gerais
}

\author{
[Detecção molecular e relação filogenética de cepas selvagens do vírus da cinomose canina \\ em cães sintomáticos oriundos de Uberlândia, Minas Gerais] \\ S.A. Headley ${ }^{1}$, T.R. Santos $^{2}$, L. Bodnar ${ }^{1}$, J.P.E. Saut ${ }^{2}$, A.P. Silva ${ }^{1}$, A.F. Alfieri ${ }^{1}$, \\ A.A. Medeiros $^{2}$, N.P. Soares ${ }^{2}$, A.A. Alfieri ${ }^{1}$ \\ ${ }^{1}$ Universidade Estadual de Londrina - UEL - Londrina, PR \\ ${ }^{2}$ Universidade Federal de Uberlândia - UFU - Uberlândia, MG
}

\begin{abstract}
This study investigated the occurrence of canine distemper virus (CDV) by evaluating the presence of viral RNA within urine samples of dogs from Uberlândia, MG, with clinical manifestations suggestive of infection by CDV by targeting the CDV N gene. Of the clinical samples collected ( $n=33)$, CDV viruria was detected in $45.5 \%$. Five dogs died spontaneously; all had characteristic CDV-associated histopathological alterations and demonstrated CDV viruria. Statistical analyses revealed that the age, gender, breed, or the organ system of the dog affected had no influence on the occurrence of canine distemper. Myoclonus and motor incoordination were the most significant neurological manifestations observed. A direct association was observed between keratoconjunctivitis and dogs with CDV viruria. These findings suggest that CDV viruria in symptomatic dogs might not be age related, and that symptomatic dogs can demonstrate clinical manifestations attributed to CDV without viruria identified by RT-PCR. Additionally, the results of the sequence identities analysed have suggested that all Brazilian wild-type strains of CDV currently identified are closely related and probably originated from the same lineage of CDV. Nevertheless, phylogenetic analyses suggest that there are different clusters of wild-type strains of CDV circulating within urban canine populations in Brazil.
\end{abstract}

Keywords: canine distemper, viruria, phylogeny, epidemiology

\section{RESUMO}

A presença do ácido nucleico (RNA) do vírus da cinomose canina (CDV) foi avaliada por meio da amplificação parcial do gene $N$ pela técnica $R T-P C R$ realizada em urina de cães provenientes de Uberlândia, Minas Gerais, que apresentavam sinais clínicos sugestivos de cinomose. Das 33 amostras de urina avaliadas, o CDV foi identificado em 45,5\%. Em cinco cães que morreram espontaneamente, além da excreção do CDV na urina, foram observadas alterações histopatológicas associadas à infecção por esse vírus. Análises estatísticas demonstraram que a idade, gênero, raça e o sistema orgânico comprometido dos cães avaliados não exerceram influência no diagnóstico da cinomose canina. Mioclonia e incoordenação motora foram as manifestações neurológicas que apresentaram frequência de ocorrência significativa $(P<0,05)$. Uma associação direta foi observada entre a presença de ceratoconjuntivite e a identificação de virúria pelo $C D V$. Esses achados sugerem que a excreção do CDV pela urina em cães com sinais clínicos compatíveis com cinomose pode não ser relacionada com a idade do animal, e que animais sintomáticos podem apresentar manifestações clínicas atribuídas ao CDV, porém sem a caracterização de virúria por RT-PCR. Adicionalmente, análises filogenéticas sugerem que várias cepas de CDV podem estar circulando em populações caninas de áreas urbanas no Brasil.

Palavras-chave: cinomose canina, virúria, filogenia, epidemiologia

Recebido em 22 de julho de 2013

Aceito em 20 de novembro de 2014

E-mail: selwyn.headley@uel.br 


\section{INTRODUCTION}

Canine distemper virus (CDV) is a Morbillivirus that produces canine distemper (CD) which can have several clinical manifestations in dogs and other canids. CDV is the main cause of mortality in some urban canine populations in Brazil (Headley and Graça, 2000), and produces economic loss estimated at US\$147.5-160.3 million per year to the local economy (Headley et al., 2012). The prevalence of CDV has been well described in important cities such as Santa Maria (Headley and Graça, 2000; Dezengrini et al., 2007), Londrina (Amude et al., 2011; Headley et al., 2013), São Paulo (Aguiar et al., 2012), and Belo Horizonte (Del Puerto et al., 2010). However, there is no information regarding $\mathrm{CD}$ from the region of Uberlândia, Minas Gerais (MG), Midwest Brazil.

The phylogenetic relationship of Brazilian wildtype strains of CDV has been investigated by a few studies, where it was suggested that several wildtype strains of CDV might be circulating within distinct geographical locations of Brazil (Headley et al., 2013; Negrão et al., 2013), and that the Brazilian wild-type strains of CDV probably were originated from a European linage (Negrão et al., 2013). Consequently, the understanding of disease dynamics within Brazil is fundamental for the implementation of control strategies and vaccination programmes. This study investigated the occurrence of CDV in symptomatic dogs from Uberlândia/MG, the possible associations relative to the detection of this agent, and the phylogenetic relationship of strains of CDV circulating in urban canine populations of Brazil.

\section{MATERIALS AND METHODS}

All dogs were obtained from animals routinely treated at the Veterinary Teaching Hospital, Universidade Federal de Uberlândia, and/or housed at an animal shelter in Uberlândia/MG. Only dogs with clinical manifestations suggestive of infection by CDV (Amude et al., 2007; Headley et al., 2012) from February to September 2012 were included in this study. The main clinical signs considered as CDV-induced disease included pulmonary infection (bronchopneumonia, ocular-nasal purulent secretions), cutaneous lesions (abdominal pustules), neurological manifestations (e.g., myoclonus, convulsions, ataxia, locomotory difficulties, and motor incoordination), and hard-pad disease (hyperkeratosis).
Urine samples were collected, via cystocentesis or urethral catheters, from all dogs and maintained at $20{ }^{\circ} \mathrm{C}$ until used for molecular diagnostics. Routine necropsy was performed on dogs that died spontaneously; from these, selected tissue fragments were collected, fixed by immersion in $10 \%$ buffered formalin solution, and routinely processed for histopathological evaluation.

Data relative to the age, sex, breed, and clinical manifestations of all dogs were collected and tabulated. All animals were arranged in predetermined age-related groups (Dezengrini et al., 2007; Headley et al., 2012) in an attempt to determine possible associations between age, organ systems affected, the neurological manifestations, and the type of infection.

Statistical analyses were done by the Chi-Square or Fisher analytical methods using the Minitab 15 (Minitab Inc ${ }^{\circledR}$, Pennsylvania, USA) software. An association was considered significant when $P \leq$ 0.05 .

All urine samples were processed for RNA extraction (Alfieri et al., 2006) and then used in RT-PCR assays designed to amplify the 287-base pair (bp) fragment of the CDV nucleoprotein gene (Headley et al., 2009). Positive control consisted of viral RNA from a previous case (Headley et al., 2009); nuclease-free water (Invitrogen Corporation, Carlsbad, CA, USA) served as negative controls in all RT-PCR assays. All obtained PCR products were separated by electrophoresis in $2 \%$ agarose gels, stained with ethidium bromide, and examined under ultraviolet light.

The RT-PCR products were purified (illustraGFX PCR DNA and Gel Band Purification Kit; GE Healthcare, Buckinghamshire, UK) and submitted for direct sequencing using the forward and reverse primers. The partial nucleotide sequences obtained were initially compared with those deposited in GenBank using the BLAST (http://www.ncbi.nlm.nih.gov/BLAST) program. Phylogenetic tree and sequence alignments were created by MEGA 5.2.1 (Tamura et al., 2011) constructed by the Maximum-Likelihoodmethod, based on 1,000 bootstrapped data sets. Sequences of the Phocine distemper virus were included as an out-group to provide stability to the created tree. Sequence identity tables were generated by using the software BioEdit 7.2 (Hall, 1999). 


\section{RESULTS}

Thirty-three dogs of both sexes (males 20; females 13) were evaluated, but no statistical difference was observed when the genders of these were compared. Mongrels $(n=23)$ were super represented between the breeds of dogs that demonstrated CDV viruria; the age of the dogs ranged from 6 months to 15 years (data not shown).

Most dogs demonstrated more than one of the clinical manifestations evaluated; 86.7\% (13/15) of these had neurological signs. Although neurological manifestations were more frequent in dogs with CDV viruria (Table 1), no significant difference was observed when the clinical manifestations based on the organ systems affected were compared with the age of the animals. CDV viruria was more frequently identified in dogs between 0 to 6 months of age, but the age of the affected dog demonstrated no statistical difference when the number of CDVpositive dogs was compared (data not shown).

Table 1. The clinical manifestations based on the systems affected relative to age distribution in dogs with canine distemper virus viruria

\begin{tabular}{lcccc}
\hline $\begin{array}{c}\text { Clinical manifestations } \\
\text { by system affected }\end{array}$ & $\begin{array}{c}0-6 \text { months } \\
(n=5)\end{array}$ & $\begin{array}{c}\text { Age distribution }(\%) \\
\text { 7 months }-1 \text { year } \\
(n=6)\end{array}$ & $\begin{array}{c}>1-5 \text { years } \\
(n=4)\end{array}$ & $p$ \\
\hline Cutaneous & 0 & 0 & 0 & - \\
Gastroenteritis & 0 & 0 & 0 & - \\
Hemoparasites & $0 \mathrm{a}$ & $3(50)$ & $1(25)$ & $p=0.1743$ \\
Hyperkeratosis & 0 & 0 & $1(25)$ & $p=0.2292$ \\
Hyperthermia & $0 \mathrm{a}$ & $1(16.7) \mathrm{a}$ & $0 \mathrm{a}$ & $p=0.4477$ \\
Keratoconjunctivitis & $2(40) \mathrm{a}$ & $3(33.3) \mathrm{a}$ & $3(75) \mathrm{a}$ & $p=0.4049$ \\
Neurological & $4(80) \mathrm{a}$ & $5(83.3) \mathrm{a}$ & $4(100) \mathrm{a}$ & $p=0.6488$ \\
Respiratory & $2(40) \mathrm{a}$ & $3(50) \mathrm{a}$ & $0 \mathrm{a}$ & $p=0.2405$ \\
\hline
\end{tabular}

Similar letters in the same line indicate that there is no significant difference by the Chi-Square test.

However, the occurrence of myoclonus and motor incoordination was more frequent within all age groups and was significantly different $(p=0.0026)$ when compared with other neurological symptoms observed (Table 2).
Although myoclonus was one of the most frequent clinical manifestations observed, CDV viruria was not detected in one dog with myoclonus and nasal hyperkeratosis.

Table 2. Frequency of the neurological manifestations observed in thirteen dogs with canine distemper virus viruria

$\begin{array}{lcccc}\hline \multirow{2}{*}{\begin{array}{c}\text { Principal neurological } \\ \text { manifestations }\end{array}} & \multicolumn{3}{c}{\text { Age range (years) }} & \text { Frequency } \\$\cline { 2 - 4 } & $\left.0-0.5 & 0.6-1 & >1-5\end{array}\right)$

Similar letters within the same column indicate that there is a significant difference $(p=0.0026)$ by the Chi-Square Test. 
No significant difference between the clinical manifestations of CDV-positive $\operatorname{dogs}$ and those that were negative by the RT-PCR assay (Figure 1) was observed when these parameters were compared by the Fischer Test. However, statistical difference $(p=0.0491)$ was observed (Figure 1) when keratoconjunctivitis was associated with the detection of CDV RNA in urine samples.

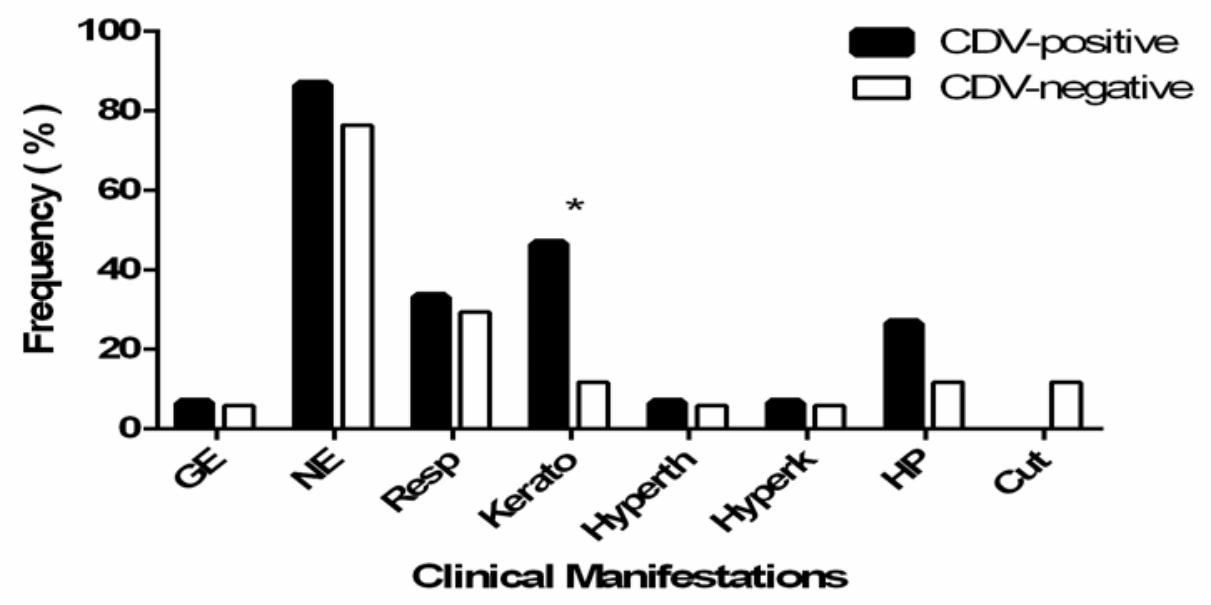

Figure 1. Comparative analysis of the clinical manifestations of dogs with canine distemper virus viruria $(n=15)$ by RT-PCR with those that were negative $(n=18)$.

Legend: GE, Gastroenteritis; NE, Neurological; Resp, Respiratory; Kerato, Keratoconjunctivitis; Hyperth, Hyperthermia; Hyperk, Hyperkeratosis; HP, hemoparasites; Cut; Cutaneous. (*), significant statistical difference $(p=0.0491)$ by the Fischer Test.

CDV was identified in $45.5 \%(15 / 33)$ of the urine samples evaluated. The desired nucleotide sequences (GenBank accession numbers $\mathrm{KC} 812375, \mathrm{KC} 812376$, and $\mathrm{KC} 812377)$ of the CDV N gene were sequenced from three dogs. These demonstrated $99-100 \%$ identity when compared with other strains deposited in GenBank by the BLAST program.

Phylogenetic analyses revealed that the Brazilian wild-type strains of CDV clustered in four groups, and two of these contained only Brazilian strains. The strains derived from this study clustered with one from the state of São Paulo (SP). Additionally, sequences from the states of Rio Grande do Sul (RS), Paraná (PR), and SP formed the largest cluster of Brazilian wild-type strains. Strains from the city of Maringá/PR clustered with strains from the USA and China. The GenBank accession numbers of the sequences used for phylogenetic analyses in this study are given in Figure 2.

All Brazilian wild-type strains of CDV demonstrated sequence identities that varied from $94-100 \%$, and were $98-100 \%$ similar to strains from other geographical regions when the generated matrix identity table (data not shown) was analysed. The strains derived from this study revealed identity of $94-99 \%$ with other wild-type strains, the lowest percentage (94\%) being associated with the strain derived from a dog that had severe canine distemper encephalitis (CDE). Some wild-type strains from the states of SP and RS had $100 \%$ identities with other Brazilian strains. The two strains from the city of Maringá/PR, derived from neonates that died suddenly due to $\mathrm{CDV}$, had $100 \%$ identity between each other but identities of $98-99 \%$ with other strains from PR and other Brazilian states.

Five dogs died spontaneously; all were submitted for necropsy. The most significant findings were non-suppurative meningoencephalitis $(n=4)$; white matter demyelination of the cerebellum associated with intranuclear eosinophilic inclusion bodies within astrocytes $(n=3)$; and ballooning degeneration of the transitional epithelial cells of the urinary bladder associated with intracytoplasmic eosinophilic inclusion bodies $(n=3)$. Other significant findings included discrete non-suppurative myocarditis and moderate interstitial pneumonia. 


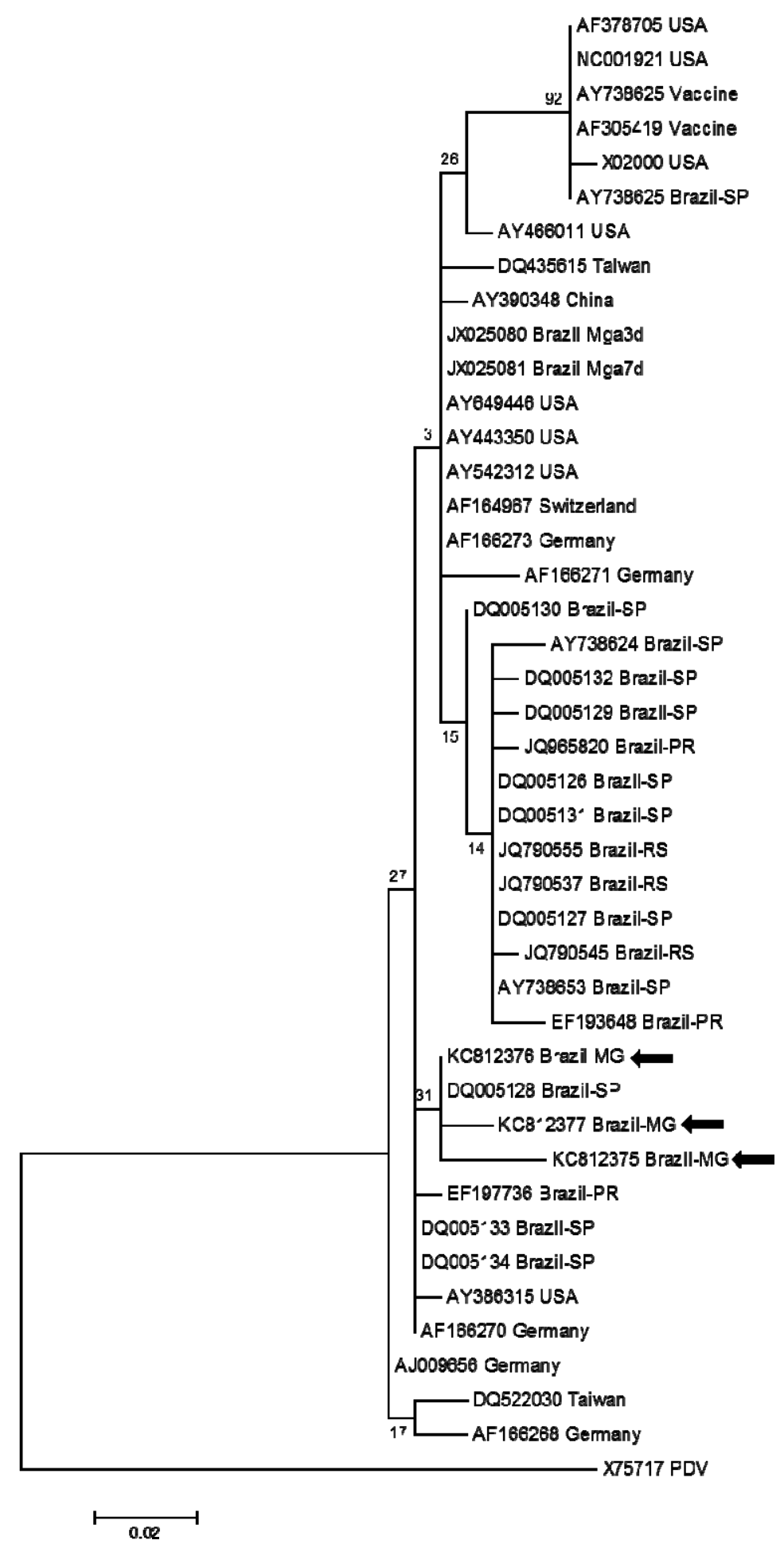

Figure 2. The phylogenetic relationship of selected wild-type strains of canine distemper virus based on the nucleoprotein gene. The GenBank accession numbers and the country of origin of the sequences used are given. The strains derived from this study are highlighted (arrows). Phocine distemper virus served as the out-group.

Legend: MG; Minas Gerais; PR, Paraná; RS, Rio Grande do Sul; SP, São Paulo; Mga, Maringá/PR. 


\section{DISCUSSION}

The clinical manifestations and histopathological findings observed in the five dogs necropsied are consistent with those associated with CDVinduced infections (Silva et al., 2009) while the histopathological patterns are typical of acute demyelinating distemper encephalitis (Silva et al., 2009; Headley et al., 2012). Further, RT-PCR assays detected CDV viruria in these dogs, and sequencing revealed partial sequences of the CDV $\mathrm{N}$ gene from three urine samples. These findings confirmed the participation of $\mathrm{CDV}$ in the etiopathogenesis of the disease manifestations observed in these dogs; similar results have been described (Amude et al., 2007; Headley et al., 2009; Headley et al., 2013). Additionally, RT-PCR identified CDV viruria in an additional ten dogs with diverse clinical manifestations (neurological and nonneurological) that were attributed to $\mathrm{CD}$, indicating that these other dogs were also infected by CDV. Similar results were observed in dogs with neurological manifestations suggestive of CDV but with molecular confirmation in some of the affected dogs (Amude et al., 2007). These results suggest that not all dogs with clinical manifestations suggestive of $\mathrm{CD}$ can demonstrate $\mathrm{CDV}$ viruria by RT-PCR. Nevertheless, the sensitivity of the diagnostic method used during this investigation cannot be totally overlooked as contributing to the results herein described.

Statistical analyses of the results from this study have demonstrated that the age of the affected dogs had no effect on the number of dogs with CDV viruria or on the clinical manifestations observed by these animals. Although histopathological evaluation was only possible for five dogs, these findings cannot be overlooked. Considering that the histopathological pattern of the brain dysfunction of the dogs necropsied is characteristic of acute demyelinating CDE, these results suggest that this form of CDV-induced brain lesion is likely to occur in dogs irrespective of the age of the affected animal. These findings correlate with recent studies (Silva et al., 2009; Headley et al., 2012) that have suggested that the age-related susceptibility to CDV infection as proposed (Krakowka and Koestner, 1976) might not be an appropriate characterization of $\mathrm{CDE}$, particularly for local conditions.
The histopathological findings of the five dogs that died spontaneously can be attributed to complications associated with $\mathrm{CDE}$ with systemic manifestations of CDV-induced infection in four of these; one dog had systemic $\mathrm{CD}$ without $\mathrm{CDE}$. These findings confirm the wide spectrum of lesions associated with CDV (Headley and Sukura, 2009; Silva et al., 2009). Furthermore, the non-suppurative myocarditis observed in two dogs can be attributed to systemic CDV-induced infections; similar results were described in a puppy with systemic CD as demonstrated during an immunohistochemical (IHC) investigation (Headley and Sukura, 2009).

Although mongrel dogs were overrepresented during this study, it was not possible to establish a significant statistical relationship between the breeds of dogs infected and susceptibility to infection by CDV; similar results have been described (Tipold et al., 1992). Nevertheless, epidemiological data has suggested that mongrels are comparatively more frequently infected by CDV compared to their purebred counterparts (Headley and Graça, 2000), and might be the reservoir of this virus within urban canine populations of Brazil (Headley et al., 2012). Furthermore, mongrels are more apt to be infected by $\mathrm{CDV}$ due to their roaming habits (Headley and Graça, 2000), and are not frequently immunized against common infectious diseases.

It was not possible to establish any statistical relationship between the gender of the dogs and CDV viruria; other studies (Tipold et al., 1992; Headley and Graça, 2000) have also concluded that the gender of the dogs infected does not seem to have any influence on the susceptibility to become infected by CDV. Furthermore, since gastrointestinal and respiratory manifestations were equally observed in CDV-positive and negative dogs, these clinical signs should not be directly associated with $\mathrm{CD}$, primarily because these symptoms can be observed in other common canine infectious diseases. However, keratoconjunctivitis seems to be directly associated $(p=0.0491)$ with CDV viruria, and should be used as a clinical indicator of CD. Although one dog had nasal hyperkeratosis and myoclonus, CDV viruria was not confirmed by RT-PCR; suggesting that this dog might have been infected but not identified with the diagnostic method used during this investigation. 
This is because confirmation of CDV in cases of hyperkeratosis has been demonstrated by IHC even in cases when the lesion was discrete (Headley and Sukura, 2009).

Statistical evaluation of the neurological manifestations observed in the dogs that demonstrated CDV viruria revealed interesting results. Myoclonus and motor incoordination were the most frequent neurological signs observed in the dogs with CDV viruria during this study, and these clinical manifestations were statistically significant $(p=0.0026)$ from the other neurological alterations observed. Alternatively, statistical evaluations of the neurological manifestations of $181 \mathrm{dogs}$ infected by CDV have demonstrated that there were significant differences between the ages of dogs infected by CDV (Headley et al., 2012). Most of the neurological manifestations observed in the dogs with CDV viruria have been associated with CD (Tipold et al., 1992; Koutinas et al., 2002; Amude et al., 2007); however these studies did not analyse the clinical observations statistically. Nevertheless, most studies that have investigated the occurrence of CDV-induced neurological manifestations have demonstrated that myoclonus is the most frequently observed sign in dogs with CDE (Tipold et al., 1992; Koutinas et al., 2002; Amude et al., 2007). However, not all dogs that demonstrated myoclonus had CDV viruria; similar results using other clinical samples have been described (Koutinas et al., 2002; Amude et al., 2007). Hence, myoclonus should be considered as an excellent indicator of CDV-induced infections, but not diagnostic for CDE; since myoclonus was observed in other canine infectious diseases (Tipold et al., 1992).

The results of these initial, but on-going, phylogenetic studies have revealed that the Brazilian wild-type strains of CDV have formed four clusters and two of these contained only Brazilian strains, suggesting that different wildtype strains might be circulating in these geographical locations; similar results have been described (Headley et al., 2012; Headley et al., 2013; Negrão et al., 2013). However, all Brazilian strains demonstrated sequence identities that varied between 94-100\%, suggesting that these strains probably originated from the same lineage of CDV, as was proposed (Negrão et al., 2013). Interestingly, strains from two cities in PR (Londrina and Maringá), separated by only $100 \mathrm{~km}$, were phylogenetically distant, not being in the same cluster but with sequence identities that varied from $98-99 \%$; similar differences were also identified when CDV strains based on the hemagglutinin $(\mathrm{H})$ gene from these two cities were analysed (Negrão et al., 2013).

Furthermore, it was recently shown that there is divergence between vaccine and wild-type strains of CDV circulating within some Brazilian cities (Negrão et al., 2006) is probably resulting in the antigenic drift between CDV wild-type and vaccine strains. Similar differences between vaccine and novel wild-type strains of CDV have been identified in South Africa (Woma et al., 2010) and Europe (Martella et al., 2006), and might be the key to explain the several outbreaks of $\mathrm{CD}$ in urban vaccinated canine populations (Woma et al., 2010; Negrão et al., 2013). Antigenic drift relative to outbreaks of CD has also been associated with the concomitant presence of other viral agents within commercial vaccines (Woma et al., 2010). Additionally, these phylogenetic results suggest that the wildtype strains of CDV circulating in Brazil might have originated from Europe, and support the theory that the South American clade of CDV strains with its European counterparts might represent the largest group of CDV strains circulating worldwide (Negrão et al., 2013). Nevertheless, these initial phylogenetic results must be complimented by a more extensive investigation of the distribution of CDV wildtype strains in all geographical regions of Brazil targeting the CDV $\mathrm{H}$ gene. A study has been initiated and the early results are supportive of the maintenance of more than one cluster of CDV wild-type strains within continental Brazil (Bodnar, L; personal communication). It must be stressed that the understanding of the impacts of $\mathrm{CD}$ on local canine populations underscores the importance of CDV within Brazil, considering the financial resources injected into the local economy annually to curb the systemic effects of CDV-related clinical manifestations (Headley et al., 2012). 


\section{CONCLUSION}

This study has demonstrated that CDV viruria was identified in $45.5 \%$ of the dogs evaluated with clinical manifestations suggestive of $\mathrm{CD}$, and the identification of this pathogen was not statistically related to sex, age, gender, or organ system of the dog affected. However, myoclonus seems to be the most frequent neurological manifestation directly associated with CDE. Phylogenetic analyses have shown that the Brazilian wild-type strains of CDV form several clusters suggesting that different types of CDV might be circulating in diverse geographical locations, although these strains have remarkably similar sequence identities.

\section{ACKNOWLEDGEMENTS}

Drs Selwyn A. Headley, João Paulo E. Saut, Alice F. Alfieri, and Amauri A. Alfieri are recipients of National Council for Scientific and Technological Development (CNPq; Brazil) fellowships.

\section{REFERENCES}

AGUIAR, D.M.; AMUDE, A.M.; SANTOS, L.G.F. et al. Canine distemper virus and Toxoplasma gondii co-infection in dogs with neurological signs. Arq. Bras. Med. Vet. Zootec., v.64, p.221-224, 2012.

ALFIERI, A.A.; PARAZZI, M.E.; TAKIUCHI, E. et al. Frequency of group A rotavirus in diarrhoeic calves in Brazilian cattle herds, 19982002. Trop. Anim. Health. Prod., v.38, p.521526, 2006.

AMUDE, A.M.; ALFIERI, A.A.; ALFIERI, A.F. Clinicopathological findings in dogs with distemper encephalomyelitis presented without characteristic signs of the disease. Res. Vet. Sci., v.82, p.416-422, 2007.

AMUDE, A.M.; HEADLEY, S.A.; ALFIERI, A.A. et al. Atypical necrotizing encephalitis associated with systemic canine distemper virus infection in pups. J. Vet. Sci., v.12, p.409-412, 2011.

DEL PUERTO, H.L.; VASCONCELOS, A.C.; MORO, L. et al. Canine distemper virus detection in asymptomatic and non vaccinated dogs. Pesq. Vet. Bras., v.30, p.132-138, 2010.
DEZENGRINI, R.; WEIBLEN, R.; FLORES, E.F. Soroprevalência das infecções por parvovírus, adenovírus, coronavírus canino e pelo vírus da cinomose em cães de Santa Maria, Rio Grande do Sul, Brasil. Cienc. Rural., v.37, p.183-189, 2007.

HALL, T.A. BioEdit: A user-friendly biological sequence alignment editor and analysis program for Windows 95/98/NT. Nucleic. Acids. Symp., v.41, p.95-98, 1999.

HEADLEY, S.A.; ALFIERI, A.A.; FRITZEN, J.T.T. et al. Concomitant canine distemper, infectious canine hepatitis, canine parvoviral enteritis, canine infectious tracheobronchitis, and toxoplasmosis in a puppy. J. Vet. Diagn. Invest., v. 25, p. 112 - 118, 2013.

HEADLEY, S.A.; AMUDE, A.M.; ALFIERI, A.F. et al. Molecular detection of canine distemper virus and the immunohistochemical characterization of the neurologic lesions in naturally occurring old dog encephalitis. J. Vet. Diagn. Invest., v.21, p.588-597, 2009.

HEADLEY, S.A.; AMUDE, A.M.; ALFIERI, A.F. et al. Epidemiological features and the neuropathological manifestations of canine distemper virus-induced infections in Brazil: a review. Semin. Cienc. Agrar., v.33, p.1945-1978, 2012.

HEADLEY, S.A.; GRAÇA, D.L. Canine distemper: epidemiological findings of 250 cases. Braz. J. Vet. Res. Anim. Sci., v.37, p.136-140, 2000.

HEADLEY, S.A.; SUKURA, A. Naturally occurring systemic canine distemper virus infection in a pup. Braz. J. Vet. Pathol., v.2, p.95-101, 2009.

KOUTINAS, A.F.; POLIZOPOULOU, Z.S.; BAUMGAERTNER, W. et al. Relation of clinical signs to pathological changes in 19 cases of canine distemper encephalomyelitis. J. Comp. Pathol., v.126, p.47-56, 2002.

KRAKOWKA, S.; KOESTNER, A. Age-Related Susceptibility to Infection with Canine Distemper Virus in Gnotobiotic Dogs. J. Infect. Dis., v.134, p.629-632, 1976.

MARTELLA, V.; CIRONE, F.; ELIA, G. et al. Heterogeneity within the hemagglutinin genes of canine distemper virus (CDV) strains detected in Italy. Vet. Microbiol., v.116, p.301-309, 2006. 
NEGRÃO, F.J.; GARDINALI, N.R.; HEADLEY, S.A. et al. Phylogenetic analyses of the hemagglutinin gene of the southern Brazil wildtype strains of canine distemper virus. Genet. Mol. Res., v.12, p.2549-2555, 2013.

NEGRÃO, F.J.; WOSIACKI, S.H.; ALFIERI, A.A. et al. Restriction pattern of a hemagglutinin gene amplified by RT-PCR from vaccine strains and wild-type canine distemper virus. Arq. Bras. Med. Vet. Zoot., v.58, p.1099-1106, 2006.

SILVA, M.C.; FIGHERA, R.A.; MAZZANTI, A. et al. Neuropatologia da cinomose canina: 70 casos (2005- 2008). Pesq. Vet. Bras., v.29, p.643-652, 2009.
TAMURA, K.; PETERSON, D.; PETERSON, $\mathrm{N}$. et al. MEGA5: molecular evolutionary genetics analysis using maximum likelihood, evolutionary distance, and maximum parsimony methods. Mol. Biol. Evol., v.28, p.2731-2739, 2011.

TIPOLD, A.; VANDEVELDE, M.; JAGGY, A. Neurological manifestations of canine distemper virus infection. J. Sm. Anim. Pract., v.33, p.466470, 1992.

WOMA, T.Y.; VAN VUUREN, M.; BOSMAN, A.M. et al. Phylogenetic analysis of the haemagglutinin gene of current wild-type canine distemper viruses from South Africa: lineage Africa. Vet. Microbiol., v.143, p.126-132, 2010. 